\title{
Detection, Semiquantitation, and Genetic Variation in Hepatitis C Virus Sequences Amplified from the Plasma of Blood Donors with Elevated Alanine Aminotransferase
}

Paul P. Ulrich, Joseph M. Romeo, Philip K. Lane, Irene Kelly, Lynton J. Daniel, and Girish N. Vyas

Department of Laboratory Medicine, University of California, San Francisco, California 94143-0134

\begin{abstract}
Hepatitis $\mathrm{C}$ virus $(\mathrm{HCV})$ is the predominant etiologic agent of posttransfusion non-A, non-B hepatitis, characterized by undulating elevation of alanine aminotransferase (ALT) and chronic liver disease. A commercial enzyme-linked immunosorbent assay detected antibodies to HCV (anti-HCV) in 11 specimens among 101 nontransfusable plasma units obtained from asymptomatic, volunteer blood donors with elevated levels of ALT. Using a combined reverse-transcription polymerase chain reaction (RT-PCR) assay developed by us, HCV RNA was detected in $0.6 \mathrm{ml}$ of plasma from 8 of $11(73 \%)$ of the anti-HCV-positive but in none of the 90 anti-HCV-negative specimens. The relatively low concentration of HCV RNA could be detected in the remaining three anti-HCV-positive specimens when $2.4 \mathrm{ml}$ of plasma was analyzed. The plasma concentration of virions was estimated to range from $10^{2}$ to 5 $\times 10^{7} / \mathrm{ml}$. Direct sequencing performed on the PCR-amplified HCV cDNAs ( 210 base pairs) from three specimens revealed heterogeneity between 2.5 and $8.6 \%$ at the nucleotide level and $<4 \%$ at the amino acid level. Our findings demonstrate that RT-PCR can be performed with $2.4 \mathrm{ml}$ of plasma, providing an assay for the direct detection of HCV RNA and confirming the existence of an asymptomatic carrier state for HCV infection in the apparently healthy anti-HCV-positive donors. (J. Clin. Invest. 1990, 86:1609-1614.) Key words: anti-hepatitis C virus - hepatitis $C$ virus carriers - hepatitis $C$ virus confirmatory assay $\bullet$ non-A, non-B hepatitis $\bullet$ polymerase chain reaction
\end{abstract}

\section{Introduction}

Non-A, non-B hepatitis (NANBH) ${ }^{1}$ accounts for $>90 \%$ of posttransfusion hepatitis cases, with an estimated incidence of $1-10 \%$ after blood transfusions in the United States (1). Ap-

Address reprint requests to Dr. Vyas, Box 0100, S 561, Department of Laboratory Medicine, University of California, San Francisco, CA 94143. 1990.

Received for publication 24 April 1990 and in revised form 22 June

1. Abbreviations used in this paper: ALT, alanine aminotransferase anti-HCV, antibodies to $\mathrm{HCV} ; \mathrm{CH}-\mathrm{HCV}$, chimpanzee-derived $\mathrm{HCV}$; $\mathrm{HBc}$, hepatitis B core antigen; HBsAg, hepatitis B surface antigen; $\mathrm{HBV}$ and $\mathrm{HCV}$, hepatitis $B$ and $C$ viruses; M-MLV, Moloney murine leukemia virus; NANBH, non-A, non-B hepatitis; PCR, polymerase chain reaction; RIBA, recombinant immunoblot assay; $\mathrm{RT}$, reverse transcription.

J. Clin. Invest.

(C) The American Society for Clinical Investigation, Inc.

$0021-9738 / 90 / 11 / 1609 / 06 \quad \$ 2.00$

Volume 86, November 1990, 1609-1614 proximately $50 \%$ of infected transfusion recipients develop biochemical evidence of chronic hepatitis, and $\sim 20 \%$ of recipients with chronic hepatitis subsequently develop histologic evidence of liver cirrhosis (2). Although NANBH was first described in association with blood transfusions, surveillance data from the Centers for Disease Control showed that only $5-10 \%$ of patients with NANBH have a history of blood transfusion (3).

A cDNA of the RNA genome of hepatitis $\mathrm{C}$ virus (HCV) has recently been cloned from an infected chimpanzee $(\mathrm{CH}-$ HCV) which developed NANBH after inoculation with a contaminated human factor VIII concentrate (4). Studies on the genome of HCV revealed positive-stranded RNA of $\sim 10,000$ nucleotides with distant homology to the Flaviviridae (4). Expression of a recombinant $\mathrm{HCV}$ fusion protein in yeast led to the development of immunoassays for antibodies to $\mathrm{HCV}$ (anti-HCV) in plasma and serum (5). Seroepidemiologic studies in the United States, Japan, and Europe revealed that $80-100 \%$ of patients with chronic posttransfusion NANBH have detectable levels of circulating anti-HCV (5-9). These data support the identification of $\mathrm{HCV}$ as the predominant agent of chronic posttransfusion NANBH worldwide (10). However, the frequency of detectable anti-HCV in acute resolving NANBH infections was much lower, ranging from 15 to $60 \%$ with a mean delay to seroconversion of almost 6 mo after transfusion $(3,10)$. These data emphasize the need for sensitive, direct assays for viral markers. In view of the expected low titers of HCV antigens in infected individuals, antigen assays are likely to have inherent limitations of sensitivity. Therefore, we employed reverse transcription (RT) in combination with polymerase chain reaction amplification (RT-PCR) as a sensitive direct assay for the detection of HCV RNA in plasma.

We report here the prevalence of HCV RNA in plasma from asymptomatic, volunteer blood donors with elevated alanine aminotransferase (ALT), and its correlation with the presence of anti-HCV, hepatitis B surface antigen ( $\mathrm{HBsAg}$ ), and antibodies to hepatitis B core antigen (anti-HBc). The titers of HCV cDNA were determined by serial dilution endpoint titration and PCR detection to obtain quantitative information about the virus load in infected individuals. Amplified HCV cDNAs from the three plasma specimens with the highest virus titer were directly sequenced and compared with the $\mathrm{CH}-\mathrm{HCV}$ cDNA sequence to determine the degree of genome heterogeneity among different $\mathrm{HCV}$ isolates.

\section{Methods}

Study population. Aliquots of plasma units from 101 asymptomatic, volunteer blood donors, not suitable for transfusion, were obtained from Irwin Memorial Blood Centers, San Francisco, CA. These units were collected between 17 May and 28 September 1989 and were 
rejected owing to elevated ALT levels ranging from 68 to $>700 \mathrm{IU} /$ liter (reference range from 2 to $54 \mathrm{IU} /$ liter). During this period, Irwin Memorial Blood Centers collected a total of 30,184 donor units, of which a total of 198 were rejected because of elevated ALT. We failed to obtain the remaining 97 ALT-elevated units during this period owing to logistical problems in the collection process. The plasma units were stored at $4^{\circ} \mathrm{C}$ until use.

Serological tests. All plasma units were tested for HBsAg and anti$\mathrm{HBc}$ with commercially available reagent kits (Auszyme and Corzyme, Abbott Laboratories, North Chicago, IL). Tests for antibodies to HCV were performed using the HCV antibody ELISA test system (Ortho Diagnostic Systems, Raritan, NJ) according to the manufacturer's instructions. The mean absorbance value of two positive controls was $1.860 \mathrm{OD}$ units, of three negative controls 0.033 , and the cutoff was set at 0.433 ( 0.400 units above the mean negative control $O D)$. Specimens positive for anti-HCV by ELISA were tested with the anti-HCV recombinant immunoblot assay (RIBA, Ortho Diagnostic Systems). Specimens reactive with $\mathrm{C} 100-3$ and 5-1-1 antigens were scored positive, and specimens reactive with only one antigen were scored indeterminate, according to the manufacturer's instructions.

Preparation of HBV RNA. The complete HBV (adw) genome was cloned into the transcription vector pTZ18U (Bio-Rad Laboratories, Richmond, CA) using standard methods $(11,12)$. Before in vitro transcription of the HBV template by T7 RNA polymerase the plasmid was linearized with Hind III. After transcription, the HBV DNA template was digested with RNase-free DNase (RQ1 DNase, Promega Biotek, Madison, WI) according to the manufacturer's instructions, followed by sequential extraction of the HBV RNA with phenol/chloroform/isoamyl alcohol (25:24:1), chloroform/isoamyl alcohol (24:1) and chromatography on a Sephacryl S300 spun column (PharmaciaLKB Biotechnology, Piscataway, NJ). The purified RNA was quantitated by spectrophotometry considering $1 \mathrm{OD}_{260}$ to be equivalent to 40 $\mu \mathrm{g} / \mathrm{ml}$ of HBV RNA or $6 \times 10^{5}$ molecules $/ \mathrm{pg}$. The integrity of the HBV RNA was evaluated by Northern blot hybridization as described by Ausubel et al. (12) and showed predominantly full-length transcripts.

Preparation of HCV RNA and RT into cDNA. Plasma samples (3 $\mathrm{ml})$ were diluted 1:5 in serum dilution buffer $(0.1 \mathrm{M} \mathrm{NaCl}, 0.05 \mathrm{M}$ Tris- $\mathrm{HCl} \mathrm{pH}$ 8.0, $1 \mathrm{mM}$ EDTA) and the debris was sedimented by centrifugation at $3000 \mathrm{~g}$ for $30 \mathrm{~min}$ at room temperature. The supernatants were transferred to sealable ultracentrifuge tubes and centrifuged for $2 \mathrm{~h}$ at 46,000 rpm (model 50 Ti rotor, Beckman Instruments, Inc., Fullerton, $\mathrm{CA} ; \mathrm{RCF}_{\min }=87,000 \mathrm{~g} ; \mathrm{RCF}_{\max }=191,000 \mathrm{~g}$ ) in order to pellet particles of $\geq 46$ Svedberg units. Plasma supernatants were discarded and the pellets were solubilized in $0.8 \mathrm{ml}$ of the following buffer ( $8 \mathrm{M}$ urea, $2 \%$ SDS, $0.15 \mathrm{M} \mathrm{NaCl}, 0.1 \mathrm{M}$ Tris- $\mathrm{HCl} \mathrm{pH} \mathrm{7.5,1} \mathrm{mM}$ EDTA) containing $1 \mu \mathrm{g} / \mathrm{ml}$ carrier HBV RNA. The buffer solutions were transferred to $1.7-\mathrm{ml}$ microcentrifuge tubes and extracted three times with phenol/chloroform/isoamyl alcohol; nucleic acids were precipitated from the aqueous phases with $2.5 \mathrm{vol}$ of ethanol. The RNA pellets individually prepared from 101 plasma specimens were resuspended in $0.3 \mathrm{M}$ sodium acetate, $\mathrm{pH}$ 5.2. One-fifth of each RNA specimen was used to prepare pools consisting of three or four RNA specimens. After a second precipitation with ethanol, the pooled RNA pellets were resuspended in diethyl pyrocarbonate-treated $\mathrm{dH}_{2} \mathrm{O}$ and cDNA was synthesized in a 40- $\mu$ l vol using random hexamers $\left(\mathrm{p}(\mathrm{dN})_{6}\right.$, Pharmacia-LKB Biotechnology) and Moloney murine leukemia virus (M-MLV) reverse transcriptase (Bethesda Research Laboratories, Gaithersburg, MD) as described by the manufacturer.

$P C R$ experiments. The cDNA preparations were added to a final volume of $100 \mu \mathrm{l}$ of amplification mixture containing $2 \mathrm{U}$ of Taq polymerase, $50 \mathrm{pmol}$ of each primer, $200 \mu \mathrm{M}$ of each dNTP, $10 \mathrm{mM}$ Tris (pH 8.3), $2 \mathrm{mM} \mathrm{MgCl} 2,50 \mathrm{mM} \mathrm{KCl}$, and $200 \mu \mathrm{g} / \mathrm{ml}$ gelatin. Primers for HBV cDNA amplification were PU5(GGGAGGAGATTAGGTTAA) and PU6 (AAGAAGTCAGAAGGCAAA), which amplified an 240-basepair (bp) DNA fragment. The HBV primers annealed to conserved regions upstream and downstream of the precore region and were selected on the basis of DNA sequence alignment for five different human HBV isolates (13). Primers for HCV cDNA were either JR3 (TGCTGACCACTACACAGTGG) and JR4 (GCGTCTGCAAGCAGAAGGAA) or PKL13 (CTGGTCGCATTGGGCATCAA) and PKL14 (CGTGATTGTCTCAATGGTGA) generating a 190- or a 210-bp DNA fragment, respectively. The HCV primers bind to the following nucleotide positions within the published HCV sequence: JR3, 649-668; JR4, 819-838; PKL13, 2871-2890; and PKL14, 3061-3080 (14). The amplification mixtures were overlaid with mineral oil and amplified in a DNA thermal cycler (PerkinElmer-Cetus Corp., Norwalk, CT) using a low stringency step-cycle program for 6 cycles $\left(40^{\circ} \mathrm{C}\right.$, for $30 \mathrm{~s} ; 72^{\circ} \mathrm{C}$ for $30 \mathrm{~s} ; 94^{\circ} \mathrm{C}$ for $\left.30 \mathrm{~s}\right)$, a high stringency step-cycle program for 35 cycles $\left(50^{\circ} \mathrm{C}\right.$ (for $\mathrm{HBV}$ ) or $55^{\circ} \mathrm{C}$ (for $\mathrm{HCV}$ ) for $30 \mathrm{~s} ; 72^{\circ} \mathrm{C}$ for $30 \mathrm{~s} ; 94^{\circ} \mathrm{C}$ for $30 \mathrm{~s}$ ), followed by a 5-min final extension at $72^{\circ} \mathrm{C}$

Liquid hybridization. This procedure was performed as previously described (15). Individual 30- $\mu 1$ aliquots of amplification reaction mixture were mixed with $10 \mu \mathrm{l}$ of probe mixture containing $75 \mathrm{mM}$ $\mathrm{NaCl}, 20 \mathrm{mM}$ EDTA, and 0.2 pmol oligomer probe end-labeled with $\left[\gamma-{ }^{32} \mathrm{P}\right] \mathrm{ATP}$ and T4 polynucleotide kinase to a specific activity of $\sim 4$ $\mu \mathrm{Ci} /$ pmol. Probe for amplified HBV DNA was PU7 (GCACCAGCACCATGCAACTT). Probe for JR3-JR4 amplified HCV DNA was JR5.1 (CCACAATGTTCTGGTGGAGG, nucleotide position 725-744) and for PKL13-PKL14 amplified HCV DNA, JR9 (CGGTCATGAGGGCATCGGTT, nucleotide position 2959-2989). After denaturation at $95^{\circ} \mathrm{C}$ for 5 min, hybridization in solution was carried out for $15 \mathrm{~min}$ at $37^{\circ} \mathrm{C}$. Hybridized DNA was separated from free probe on an $8 \%$ polyacrylamide (acrylamide to bis-acrylamide, 19:1) gel and visualized by autoradiography using XAR-5 film (Eastman Kodak Co., Rochester, NY). The detection limit was 1 pg of amplified HBV or HCV DNA after $16 \mathrm{~h}$ of exposure at $-70^{\circ} \mathrm{C}$.

Sequencing of amplified DNA. HCV DNA amplified with the primer pair PKL13-PKL14 by the standard PCR procedure was purified by spin dialysis in microconcentrators (Centricon model 100, Amicon Corp. Danvers, MA) (15). Direct sequencing was performed as reported by Wong et al. (16). One amplification primer ( $2 \mathrm{pmol}$ of PKL 13 or PKL14, end-labeled with $\left[\gamma{ }^{32}\right.$ P]ATP and T4 polynucleotide kinase) was annealed to $0.4 \mathrm{pmol}$ of amplified DNA, and sequencing was carried out with Sequenase (United States Biochemicals, Cleveland, $\mathrm{OH}$ ) according to the manufacturer's instructions.

\section{Results}

Serological markers for $\mathrm{HBV}$ and $\mathrm{HCV}$ in ALT-elevated plasma. 11 of the 101 plasma specimens tested positive for anti-HCV and 4 of the 11 specimens were also positive for anti-HBc. 9 of the 11 anti-HCV ELISA-positive specimens tested positive on the anti-HCV RIBA test, whereas two were indeterminate. Two anti-HCV negative plasmas were positive for anti-HBc, and one of these two was also positive for HBsAg. Table I shows the serological results of the 13 specimens positive for any of the HBV or HCV markers and includes the absorbance values of the HCV antibody ELISA test. The remaining 88 specimens not listed in Table I were negative for anti-HCV, anti-HBc, and $\mathrm{HBsAg}$.

Sensitivity of the RT-PCR amplification procedure. To determine the lower limit of RNA detection in a combined RTPCR assay, 10-fold serial dilutions of in vitro synthesized HBV RNA were reverse transcribed into $\mathrm{HBV}$ cDNA with random primers and M-MLV reverse transcriptase. The cDNA preparations were amplified with the primer pair PU5-PU6 specific for the precore/core gene of HBV. After 41 cycles of amplification the HBV DNA was hybridized in solution to the HBVspecific probe PU7 and then separated by polyacrylamide gel electrophoresis. 10-fold serial dilutions of HBV RNA, from 2 $\times 10^{6}$ to 0 molecules, were analyzed. Samples containing an initial quantity of $200 \mathrm{HBV}$ RNA molecules produced hybrid- 
Table I. Presence of Serological Markers for HBV and/or HCV in 13 Plasma Units from Asymptomatic Blood Donors with Elevated $A L T$

\begin{tabular}{cccccc}
\hline $\begin{array}{c}\text { Plasma } \\
\text { No. }\end{array}$ & Anti-HBc & HBsAg & Anti-HCV ELISA & HCV RIBA & RT-PCR \\
\hline & & & $(A)$ & & \\
26 & + & + & - & NT & - \\
28 & + & - & $+(>2.0)$ & + & + \\
32 & - & - & $+(>2.0)$ & + & ++ \\
33 & - & - & $+(>2.0)$ & + & ++ \\
35 & + & - & $+(>2.0)$ & + & +++ \\
36 & + & - & $+(>2.0)$ & + & +++ \\
37 & - & - & $+(>2.0)$ & IN & + \\
49 & - & - & $+(>2.0)$ & + & +++ \\
60 & + & - & - & NT & - \\
78 & - & - & $+(0.8)$ & + & + \\
86 & - & - & $+(>2.0)$ & + & ++ \\
88 & - & - & $+(1.6)$ & IN & $(++)$ \\
100 & + & - & $+(>2.0)$ & + & ++ \\
& & & & &
\end{tabular}

* Absorbance value: cutoff, 0.433 .

$\ddagger+$, positive; IN, indeterminate; NT, not tested.

$\S-$, negative; + , weak positive; ++ , strong positive; +++ , very strong positive with the primers JR3-JR4 and PKL13-PKL14; (++) positive only with PKL13-PKL-4.

ization signals of the expected size $(\sim 240 \mathrm{bp})$. The dilutions theoretically containing 20,2 , and 0 molecules of HBV RNA were negative. All HBV RNA dilutions were also amplified for 41 cycles without the RT step and were negative by liquid hybridization, demonstrating that the signal obtained was not generated from undigested HBV DNA used for in vitro transcription.

Detection of HCV RNA. Pools of three or four RNA specimens, each obtained from $0.6 \mathrm{ml}$ of plasma, were subjected to RT using random primers and then amplified by PCR using either the HCV-specific primer pair JR3-JR4 or PKL13PKL14. Of the 29 pools generated, three were strongly positive for HCV: pool 11 (containing specimens 31, 32, and 33), pool 12 (containing specimens 34,35 , and 36 ) and pool D (containing specimens $49,50,51$, and 52); two pools were weakly positive: pool $\mathbf{M}$ (containing specimens $86,87,88$, and 89 ), and pool $P$ (containing specimens $97,98,99$, and 100). In order to identify the source of the HCV RNA, individual RNA specimens (from $0.6 \mathrm{ml}$ of plasma), which had been used to prepare the PCR-positive pools, were similarly reverse transcribed and analyzed by PCR. HCV sequences were detected with both primer pairs in the anti-HCV-positive specimens $32,33,35,36,49,86$, and 100 ; specimen 88 was positive only with PKL13-PKL14, and the remaining anti-HCV-negative specimens used in the pools were negative with both primer pairs. Considering the detection limit of the RT-PCR procedure, we assume that the HCV-PCR-positive RNA specimens contain $>200$ target molecules and that RNA specimens with fewer targets would be negative. To determine whether the remaining anti-HCV-positive specimens 28,37 , and 78 harbor HCV in lower concentrations, RNA derived from $2.4 \mathrm{ml}$ of plasma was reverse transcribed and amplified; PCR for these specimens was positive with both HCV-specific primer pairs. These results indicate a strong correlation between the presence of circulating antibodies to the recombinant $\mathrm{HCV}$ antigen $\mathrm{C100-3}$, as tested by the anti-HCV ELISA, and the presence of HCV RNA in ALT-elevated plasma from asymptomatic blood donors.

Titration of $H C V$ cDNA preparations. Because we found a significant difference in the signal intensity of the RT-PCR assay for the different specimens, we prepared fourfold serial dilutions of individual cDNA preparations $(40 \mu \mathrm{l})$ obtained from a $0.6-\mathrm{ml}$ aliquot of plasma. The cDNA preparations of specimens $32,33,86,88$, and 100 showed no PCR signal when diluted (1:4), suggesting that these specimens harbored $\geq 200$ molecules of detectable HCV RNA in $0.6 \mathrm{ml}$ of plasma, but $<200$ molecules (detection limit) HCV RNA in $0.15 \mathrm{ml}$ of plasma (Fig. $1 A$ ). Assuming quantitative recovery of $\mathrm{HCV}$ virion RNA by ultracentrifugation and buffer treatment, we calculated that the virus concentration in these specimens is $\geq 3.3 \times 10^{2}$ and $<1.3 \times 10^{3}$ virions $/ \mathrm{ml}$ of plasma. The cDNA preparations of the strongly positive specimens 35 (Fig. $1 \mathrm{~B}$ ), 36 (Fig. $1 C$ ), and 49 (data not shown), on the other hand, had endpoint titers of $40,960,10,240$, and 10,240 , respectively. With the same assumptions, we calculated viral titers between $\geq 1.3$ and $<5.5 \times 10^{7}$ virions $/ \mathrm{ml}$ for specimen 35 and between $\geq 3.4 \times 10^{6}$ and $<1.3 \times 10^{7}$ virons $/ \mathrm{ml}$ for specimen 36 and 49. Plasma specimens 28,37 , and 78 have a calculated virus titer between $\geq 80$ and $<330$ virions $/ \mathrm{ml}$.

Sequence analysis of $H C V$ cDNA. We sequenced PKL13PKL14 amplified HCV cDNAs from the high-titer plasmas 35, 36 , and 49 to determine the degree of heterogeneity between different human isolates of $\mathrm{HCV}$ in this particular region of the genome. Because most populations of RNA viruses do not exist as a single genome species with a unique sequence, but rather as a heterogeneous mixture of related genomes, we per-
A

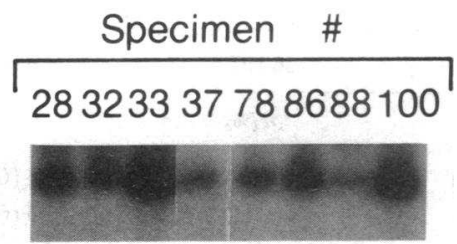

B

Specimen 35
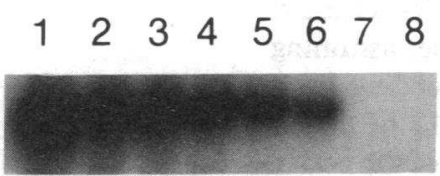

Specimen 36

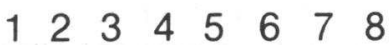

Figure 1. Autoradiogram of PKL13-PKL14-amplified HCV cDNA hybridized to the oligonucleotide probe JR9. $(A)$ RNA from an equivalent of $0.6 \mathrm{ml}$ of plasma (specimens $32,33,86,88$, and 100 ), and from an equivalent of $2.4 \mathrm{ml}$ of plasma (specimens 28,37 , and 78 ) was used. (B and $C$ ) Serial fourfold dilutions of cDNA prepared from RNA from an equivalent $0.6 \mathrm{ml}$ of plasma of $(B)$ specimen 35 and $(C)$ specimen 36 . Lane 1, 1:40; lane 2, 1:160; . . lane 8, 1:655,360. 
35-HCV: GTGGCCTACTA CCGCGGTCTT GACGTGTCCG TCATCCCGAC CAG 36-HCV: GTGGCCTACTA CCGCGGČCTT GACGTGTCĞG TCATCCCGAC CAGT̈GGCGA 49-HCV: GTGGCCTACTA CCGCGGTCTT GACGTGTCT̈G TCATCCCGڤ̆C CAGCGGCGA

2995

CH-HCV: TGTTGTCGTC GTGGCAACCG ATGCCCTCAT GACCGGCTAT ACCGGCGACT

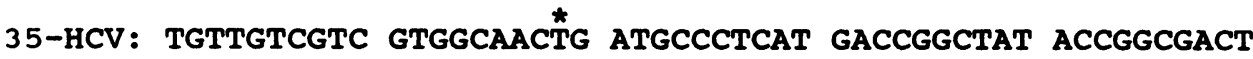

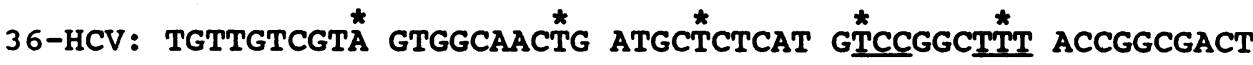

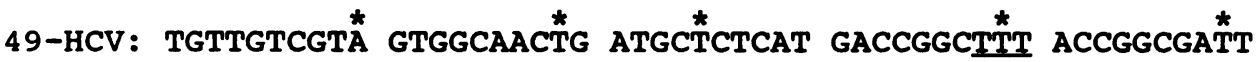
3045 CH-HCV: TCGACTCGGT GATAGACTGC AATACGTGTG TCACCCAGAC AGTCGATTTC 35-HCV: TCGACTCGGT GATAGACTGC AACACGTGTG TCACCCAGAC AGTCGA

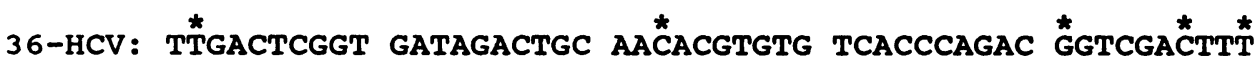

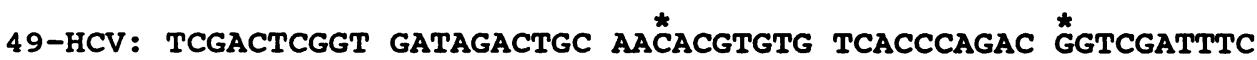

3056

CH-HCV: AGCCTTGACC CT

35-HCV: AGCCTTGACC CT

36-HCV: AGCCTTGACC C

49-HCV: AGCCTTGA $\stackrel{\star}{\mathrm{C} C}$ CT
Figure 2. Nucleotide sequence alignment of the chimpanzee-derived $(\mathrm{CH}-\mathrm{HCV})$ and three human (35, 36, and 49) HCV isolates. The sequences flanked by the primer pair PKL13-PKL14 are illustrated. Nucleotide numbering is according to the $\mathrm{CH}-\mathrm{HCV}$ sequence and nucleotides different from $\mathrm{CH}-\mathrm{HCV}$ are marked $\left({ }^{*}\right)$. The translational reading frame starts with the first nucleotide (2895) in these sequences and the underlined codons represent mutations affecting the predicted amino acid substitutions. These sequence data are available from EMBL/Gen Bank/DDBJ under accession number M55151. formed direct sequencing of amplified HCV cDNA to obtain the sequence of the most abundant HCV genome present in each of the three high-titer plasmas (17). Sequencing of the cDNA ( + ) strand was carried out by annealing the upstream amplification primer PKL13 to PKL13-PKL14-amplified HCV cDNA. For sequencing of the cDNA (-) strand, we annealed the downstream amplification primer PKL14 to independently reverse-transcribed and amplified PKL13-PKL14 cDNA. A total of 162 nucleotides (exclusive of primers) could be read on each strand. No nucleotide differences were observed, when $(+)$ strand and corresponding $(-)$ strand of any individual isolate were compared. This excludes the possibility that the observed point mutations are artifacts of RT, PCR, or sequencing. The nucleotide sequences (162 bp) of the HCV isolates from specimens 35,36 , and 49 as well as the published nucleotide sequence of the chimpanzee-derived HCV cDNA are aligned in Fig. 2. The observed point mutations occurred at 17 positions in the 162-nucleotide sequence of the HCV genome. The genetic heterogeneity between the different isolates ranged from $2.5 \%$ between $\mathrm{CH}-\mathrm{HCV}$ and $35-\mathrm{HCV}$ to $8.6 \%$ between $\mathrm{CH}-\mathrm{HCV}$ and 35-HCV (Table II). In all four HCV sequences only one reading frame is continuous. This should therefore be the translational open reading frame, assuming HCV has a flavivirus-like genetic organization coding for a single polyprotein. In this open reading frame 13 of the 17 nucleotide changes affect the third base position of the codon and do not change the amino acid sequence. Four conservative amino acid changes were observed (underlined codons in Fig. 2): two point mutations occurred in the first base position resulting in amino acid changes from threonine (ACC) to ala- nine (GCC) or serine (TCC), and the other two point mutations occurred in the second position of the codon changing tyrosine (TAT) to phenylalanine (TTT). From the deduced amino acid sequence we calculated a heterogeneity of $\leq 4 \%$ between the four HCV isolates. Therefore, the sequences of the chimpanzee-derived and the three human isolates are highly homologous in this region of the HCV genome both at the nucleotide sequence level and at the level of the predicted amino acid sequences.

\section{Discussion}

Antibody testing establishes whether an individual has responded immunologically to exposure to viral antigens, but does not distinguish whether the infectious agent was eliminated by the host's immune response or continues to persist in

Table II. Nucleotide Heterogeneity between the Four Sequences from Fig. 2

\begin{tabular}{lccc}
\hline Virus & $35-\mathrm{HCV}$ & $36-\mathrm{HCV}$ & $49-\mathrm{HCV}$ \\
\hline & & $n(\%)$ \\
CH-HCV & $4(2.5)$ & $14(8.6)$ & $10(6.2)$ \\
$35-\mathrm{HCV}$ & - & $10(6.2)$ & $10(6.2)$ \\
$36-\mathrm{HCV}$ & - & - & $11(6.8)$
\end{tabular}

Data in the table indicate the number of different nucleotides out of 162 ; values in parentheses express the difference in percent. 
the host. Sequential serum samples from prospectively followed patients with HCV-NANBH indicate a prolonged window period for seroconversion (10). This prolonged delay in antibody response suggests that some blood donors capable of transmitting $\mathrm{HCV}$ will not be detected by anti-HCV testing. A direct assay for $\mathrm{HCV}$ antigens or nucleic acids could be useful for the detection of $\mathrm{HCV}$ infection prior to seroconversion. Such an assay might also be useful to distinguish infected from immune individuals. Therefore, we have developed a combined RT-PCR amplification assay for the detection of HCV RNA isolated from plasma. The HCV RNA detected by this assay must be derived from virus particles, not only because of the ultracentrifugation step, but also because of the presence of high levels of RNase activity in plasma (data not shown) making it impossible for RNA to exist freely in plasma.

A strong correlation between the presence of anti-HCV and HCV RNA in plasma of asymptomatic blood donors was observed. All 11 anti-HCV ELISA-positive donors were positive for HCV RNA with our RT-PCR assay using two HCVspecific primer pairs in independent amplifications. The two primer pairs showed congruent results except for plasma 88 , which was only positive with PKL13-PKL14. Based on the $\mathrm{HCV}$ genome analysis and its comparison to flaviviral genome organization $(14,18)$, the primer pair PKL13-PKL14 anneals within the putative NS3 gene of HCV. This gene has been shown to be relatively conserved among the flaviviruses. The primer pair JR3-JR4 anneals to a less defined region of the HCV genome, which may correspond to the NS2 region of the flaviviruses, a region known to display very high rates of sequence divergence (18). It is possible that mutations in the JR3-JR4 binding sites in this particular isolate interfered with efficient amplification, thus making minute amounts of HCV RNA undetectable. We also note that our negative RT-PCR results on the 90 anti-HCV-negative specimens derive from assays performed on RNA from an equivalent of $0.6 \mathrm{ml}$ of plasma. These results are not, strictly speaking, comparable to the positive RT-PCR results on the three lowest-titer specimens (Nos. 28, 37, and 78), since the three positive RT-PCR results were obtained only when the assay was performed on RNA from $2.4 \mathrm{ml}$ of plasma. Our data do not rule out the possibility that some of the 90 ALT-elevated anti-HCV-negative specimens we studied might harbor $\mathrm{HCV}$ at a titer too low for detection in $0.6 \mathrm{ml}$ with our current RT-PCR protocol. However, the strong correlation of our positive RT-PCR results with the anti-HCV results suggests most or all antibodypositive plasma specimens will contain viral RNA detectable by RT-PCR, and as such are likely to be infectious.

After the PCR results were obtained, the anti-HCV RIBA test became available as a proposed confirmatory test for anti-HCV reactivity. We found that two of the 11 anti-HCV ELISA-positive specimens were indeterminate on the RIBA test. Because all 11 specimens were $\mathrm{HCV}$ PCR positive, apparently the manufacturer's definition of an indeterminate RIBA result (reactive with only one $\mathrm{HCV}$ antigen) may be too stringent.

Interestingly, in a recent report by Weiner et al. (19) seven out of nine anti-HCV positive chronic NANBH patients had HCV RNA in their livers, but the remaining two were HCV PCR negative. This might reflect biological differences between patients with chronic NANBH and asymptomatic carriers of HCV. However, it is also possible that HCV RNA was present in these two livers, but not detected by the RT-PCR assay employed. Explanations could include: $(a)$ the primers used by Weiner et al. (19) were relatively short (16-mers), suggesting less efficient specific amplification of $\mathrm{HCV}$ cDNA, and in addition the sense primer contained one mismatch (A-G) on comparison to the published $\mathrm{CH}-\mathrm{HCV}$ sequence at the extreme $5^{\prime}$ end and another mismatch (T-C) on comparison to the sequences from our three human isolates; or $(b)$ amplification was carried out by Weiner et al. (19) for only 30 cycles, even though cDNA amplification is only $35-55 \%$ efficient in comparison to $67-90 \%$ efficiency for DNA amplification $(20,21)$.

Because of the absence of specific viral markers in the past, quantitation of viral load in NANB/HCV infections could only be performed by dilutional endpoint infectivity testing in chimpanzees (22), a difficult and expensive procedure. Most investigators have found that human and chimpanzee inocula generally have titers between $10^{2}$ and $10^{4}$ chimpanzee infectious doses $/ \mathrm{ml}$, although titers of up to $10^{6}$ have been reported (22). We used the dilutional endpoint titers of HCV cDNA detection by PCR to calculate the concentration of $\mathrm{HCV}$ virions and found between $10^{2}$ and $5 \times 10^{7}$ virions $/ \mathrm{ml}$ in the different plasma specimens. In interpreting these data it must be remembered that RT-PCR is at best semiquantitative, even when employed in careful dilutional endpoint titration studies such as ours. In order to calibrate our HCV RT-PCR assay we used cloned HBV RNA; we note that slight differences in RT efficiency and PCR amplification efficiency could have led to differences in final sensitivity of $\mathrm{HBV}$ and HCV detection. Furthermore, in view of the high mutation rate characteristic of RNA viruses, RT-PCR performed on field isolates of HCV is also subject to the problem of sequence variation at the primer binding sites which may lead to differential PCR amplification efficiencies. Therefore, our HCV titration figures must be interpreted with caution; we estimate that their margin of error may be as great as plus or minus an order of magnitude. However, we also note that these figures are consistent with those obtained by chimpanzee inoculation, even though RT-PCR does not measure infectivity and nothing is known yet about the possible existence of defective HCV particles.

For a sensitive, specific, and reliable RT-PCR assay, it is important to select primer binding sites which are conserved among different human $\mathrm{HCV}$ isolates. The primer pair PKL13-PKL14 allowed efficient amplification of all HCV cDNA preparations tested so far and therefore we investigated the nucleotide heterogeneity in this particular region of the $\mathrm{HCV}$ genome. The sequences of the $\mathrm{CH}-\mathrm{HCV}$ and the three human HCV isolates are highly homologous, both at the nucleotide level and at the predicted amino acid level, in the region between these two primers.

We conclude that our RT-PCR assay for the detection of $\mathrm{HCV}$ sequences in plasma could be useful as a confirmatory test for the diagnosis of $\mathrm{HCV}$ infection. It may also provide answers to important questions concerning the natural history of $\mathrm{HCV}$ infection, such as frequency and duration of the asymptomatic $\mathrm{HCV}$ carrier state.

\section{Acknowledgments}

We thank Dr. Herbert A. Perkins, Dr. Michael P. Busch, Dr. Alan Mayer, Ruth Cordell, and staff at Irwin Memorial Blood Centers in San Francisco for providing ALT-elevated plasma units. 
This work was supported by research grant P01 HL-36589 from the National Heart, Lung and Blood Institute.

\section{References}

1. Aach, R. D., W. Szmuness, J. W. Mosley, F. B. Hollinger, R. A. Kahn, C. E. Stevens, V. M. Edwards, and J. Werch. 1981. Serum alanine aminotransferase of donors in relation to the risk of non-A non-B hepatitis in recipients. $N$. Engl. J. Med. 304:989-994.

2. Dienstag, J. L., and H. J. Alter. 1986. Non-A, non-B hepatitis: evolving epidemiologic and clinical perspectives. Semin. Liver Dis. 6:67-81.

3. Alter, M. J., and R. E. Sampliner. 1989. Hepatitis C: and miles to go before we sleep. $N$. Engl. J. Med. 321:1538-1540.

4. Choo, Q.-L., G. Kuo, A. J. Weiner, L. R. Overby, D. W. Bradley, and $M$. Houghton. 1989. Isolation of a cDNA clone derived from a blood-borne non-A, non-B viral hepatitis genome. Science (Wash. DC). 244:359-362.

5. Kuo, G., Q.-L. Choo, H. J. Alter, G. L. Gitnick, A. G. Redeker, R. H. Purcell, T. Miyamura, J. L. Dienstag, M. J. Alter, C. E. Stevens, et al. 1989. An assay for circulating antibodies to a major etiologic virus of human non-A, non-B hepatitis. Science (Wash. DC). 244:362-364.

6. VanDerPoel, C. L., H. W. Reesink, P. N. Lelie, A. LeentvaarKuypers, Q.-L. Choo, G. Kuo, and M. Houghton. 1989. Anti-hepatitis $C$ antibodies and non-A, non-B post-transfusion hepatitis in the Netherlands. Lancet. ii:297-298.

7. Kuhnl, P., S. Seidl, W. Stangel, J. Beyer, W. Sibrowski, and J. Flik. 1989. Antibody to hepatitis C virus in German blood donors. Lancet. ii:324. (Letter)

8. Krauledat, P. B., editor. 1989. Report of the Proceedings: First International Symposium: Hepatitis C Virus (14-15 September 1989, Rome, Italy). Ortho Diagnostics Systems/Chiron Corporation.

9. Esteban, J. I., L. Viladomiu, A. Gonzalez, M. Roget, J. Genesca R. Esteban, J. C. Lopez-Talavera, J. M. Hernandez, V. Vargas, M. Buti, et al. 1989. Hepatitis C virus antibodies among risk groups in Spain. Lancet. ii:294-297.

10. Alter, H. J., R. H. Purcell, J. W. Shih, J. C. Melpolder, M. Houghton, Q.-L. Choo, and G. Kuo. 1989. Detection of antibody to hepatitis $\mathrm{C}$ virus in prospectively followed transfusion recipients with acute and chronic non-A, non-B hepatitis. $N$. Engl. J. Med. 321:1494-1500.

11. Blum, H. E., A. T. Haase, J. D. Harris, D. Walker, and G. N. Vyas. 1984. Asymmetric replication of hepatitis B virus DNA in human liver: demonstration of cytoplasmic minus-strand DNA by blot analyses and in situ hybridization. Virology. 139:87-96.

12. Ausubel, F. M., R. Brent, R. E. Kingston, D. D. Moore, J. G. Seidman, J. A. Smith, and K. Struhl. 1990. Current Protocols in Molecular Biology. John Wiley \& Sons, Inc., New York.

13. Larzul, D., F. Guigue, J. J. Sninsky, D. H. Mack, C. Brechot, and J.-L. Guesdon. 1988. Detection of hepatitis B virus sequences in serum by using in vitro enzymatic methods. J. Virol. Methods. 20:227-237.

14. Houghton, M., Q.-L. Choo, and G. Kuo. NANBV Diagnostics and Vaccines. European Patent No. EP-0-318-216-A1. European Patent Office (filed 18 November 1988, published 31 May 1989).

15. Ulrich, P. P., R. A. Bhat, B. Seto, D. Mack, J. Sninsky, and G. N. Vyas. 1989. Enzymatic amplification of hepatitis B virus DNA in serum compared with infectivity testing in chimpanzees. $J$. Infect. Dis. 160:37-43.

16. Wong, C., C. E. Dowling, R. K. Saiki, R. G. Higuchi, H. A. Erlich, and H. H. Kazazian. 1987. Characterization of beta-thalassaemia mutations using direct genomic sequencing of amplified single copy DNA. Nature (Lond.). 330:384-386.

17. Steinhauer, D. A., and J. J. Holland. 1987. Rapid evolution of RNa viruses. Annu. Rev. Microbiol. 41:409-433.

18. Miller, R. H., and R. H. Purcell. 1990. Hepatitis C virus shares amino acid sequence similarity with pestiviruses and flaviviruses as well as members of two plant virus supergroups. Proc. Natl. Acad. Sci. USA. 87:2057-2061.

19. Weiner, A. J., F. Kuo, D. W. Bradley, F. Bonino, G. Saracco, C. Lee, J. Rosenblatt, Q.-L. Choo, and M. Houghton. 1990. Detection of hepatitis C viral sequences in non-A, non-B hepatitis. Lancet. 335:1-3.

20. Rappolee, D. A., A. Wang, D. Mark, and Z. Werb. 1989. Novel method for studying mRNA phenotypes in single or small numbers of cells. J. Cell. Biochem. 39:1-11.

21. Saiki, R. K., D. H. Gelfand, S. Stoffel, S. J. Scharf, R. Higuchi, G. T. Horn, K. B. Mullis, and H. A. Erlich. 1988. Primer-directed enzymatic amplification of DNA with a thermostable DNA polymerase. Science (Wash. DC). 239:487-491.

22. Bradley, D. W. 1985. The agents of non-A, non-B viral hepatitis. J. Virol. Methods. 10:307-319. 